\title{
MODEL JIGSAW SEBAGAI ALTERNIATIF PENINGKATAN HASIL BELAJAR BAHASA INDONESIA MATERI TEKS RESENSI KELAS XI MIA 2 MAN 3 BLITAR
}

\author{
MUFARROCHAH \\ MAN 3 Blitar \\ e-mail: mufawawa@yahoo.co.id
}

\begin{abstract}
ABSTRAK
Penelitian ini bertujuan mendeskripsikan penerapan Model Jigsaw dan peningkatan hasil belajar Bahasa Indonesia pada materi teks resensi siswa kelas XI MIA 2 MAN 3 Blitar. Penelitian ini merupakan penelitian tindakan kelas yang terdiri atas dua siklus yang setiap siklus terdiri atas empat tahapan. Siklus 1 dan siklus 2 masing-masing terdiri dari 2 kali pertemuan. Dari hasil yang telah diperoleh aktivitas guru pada siklus 1 ketuntasan aktivitas guru mendapatkan rata-rata persentase sebesar 94\% dengan kualifikasi sangat baik. Pada siklus 2 ketuntasan aktivitas guru mendapatkan rata-rata persentase sebesar 97\% dengan kualifikasi sangat baik. Pada siklus 1 aktivitas siswa memperoleh presentase rata-rata sebesar $65 \%$. Pada siklus 2 aktivitas siswa memperoleh presentase rata-rata sebesar $90 \%$. Hasil belajar materi teks resensi melalui model Jigsaw diperoleh dari hasil penelitian melalui rata-rata nilai akhir pada siklus 1 pertemuan 1 dengan persentase $76 \%$. Pada siklus 1 pertemuan kedua dengan persentase $77 \%$ dengan rata-rata persentase 76,5\%. Sedangkan pada siklus 2 pertemuan 1 dengan persentase $79 \%$ dan untuk siklus 2 pertemuan keduadengan persentase $84 \%$ dengan rata-rata persentase $81,5 \%$. Hasil ini menunjukkan bahwa model Jigsaw dapat digunakan untuk meningkatkan hasil belajar bahasa Indonesia materi teks resensi di kelas XI MIA 2 MAN 3 Blitar.
\end{abstract}

Kata Kunci: model Jigsaw, hasil belajar, teks resensi.

\section{PENDAHULUAN}

Guru dituntut untuk mengembangkan berbagai potensi yang dimilikinya secara optimal sehingga dapat melaksanakan tugas sesuai dengan tuntutan masyarakat. Begitu pun dalam pembelajaran bahasa dan sastra Indonesia, guru diharapkan tidak memakai cara-cara lama yang masih menggambarkan dominasi guru dalam pembelajaran secara sepenuhnya. Guru dituntut menggunakan berbagai metode yang bisa meningkatkan hasil pembelajaran. Untuk dapat mengembangkan potensi yang ada di dalam diri siswa maka perlu adanya perbaikan dalam proses pembelajaran. "Kualitas dan keberhasilan pembelajaran sangat dipengaruhi oleh ketepatan dalam memilih dan mengembangkan model serta metode pembelajaran" (Budiyanto, 2004:345). MenuruT Zamzani (2015) pembelajaran kooperatif merupakan model pembelajaran yang memprioritaskan siswa lebih aktif dalam kegiatan pembelajaran. Dalam pembelajaran kooperatif siswa diarahkan untuk bekerjasama dan saling membantu dalam kelompok untuk memahami materi suatu pelajaran sehingga tumbuh rasa sosial yang tinggi diantara sesama anggota dalam kelompok tersebut.

Salah Satu dari model pembelajaran kooperatif menggunakan tipe Jigsaw adalah sebuah strategi belajar yang dapat menumbuhkan komunikasi efektif, menciptakan suasana belajar yang aktif, dan dapat memberikan hasil belajar yang memuaskan. Banyak penelitian menunjukkan bahwa pengajaran oleh rekan sebaya (peer teaching) ternyata lebih efektif dari pada pengajaran oleh guru, penerapan pembelajaran kooperatif tipe Jigsaw pada materi suatu pelajaran dapat meningkatkan aktivitas dan hasil belajar siswa, juga dapat mendorong komunikasi yang baik dan sosial yang tinggi antarsesama siswa.

Alasan penerapan model Jigsaw pada siswa kelas XI MIA 2 MAN 3 Blitar, sebagai berikut. (1) Memberikan kesempatan kepada para siswa untuk menggunakan keterampilan bertanya dan membahas suatu masalah. (2) Mengembangkan bakat kepemimpinan dan mengajar keterampilan berdiskusi. (3) Para siswa lebih aktif berpartisipasi dalam diskusi. 
(4) Memberikan kesempatan kepada para siswa untuk mengembangkan rasa saling menghargai dan menghormati pribadi teman (Roestiyah, 1998).

Dengan menggunakan model pembelajaran Jigsaw di Kelas XI MIA 2 MAN 3 Blitar dapat meningkatkan hasil belajar siswa, meningkatkan keaktifan siswa, melatih kematangan sosial siswa, siswa dapat melakukan diskusi dengan sungguh-sungguh, serta secara bersamasama dapat meningkatkan pemahaman materi siswa dengan menciptakan kondisi belajar yang lebih nyaman dan menyenangkan. Berdasarkan uraian di atas maka peneliti melaksanakan Penelitian Tindakan Kelas (PTK) dengan judul Peningkatan Hasil Belajar Bahasa Indonesia pada Materi Teks Resensi melalui Model Jigsaw di Kelas XI MIA 2 MAN 3 Blitar.

\section{METODE PENELITIAN}

Prosedur penelitian yang digunakan dalam penelitian ini adalah penelitian tindakan kelas. Rancangan yang digunakan sesuai dengan pendapat Kemmis dan Mc Taggart dalam Astuti (2015:22). Penelitian Tindakan Kelas (PTK) ini dilaksankan dalam dua siklus. Setiap siklus terdiri dari 4 (empat) komponen pokok, meliputi: (1) perencanaan (planning), (2) tindakan (acting), (3) pengamatan (observing), (4) refleksi (reflecting).

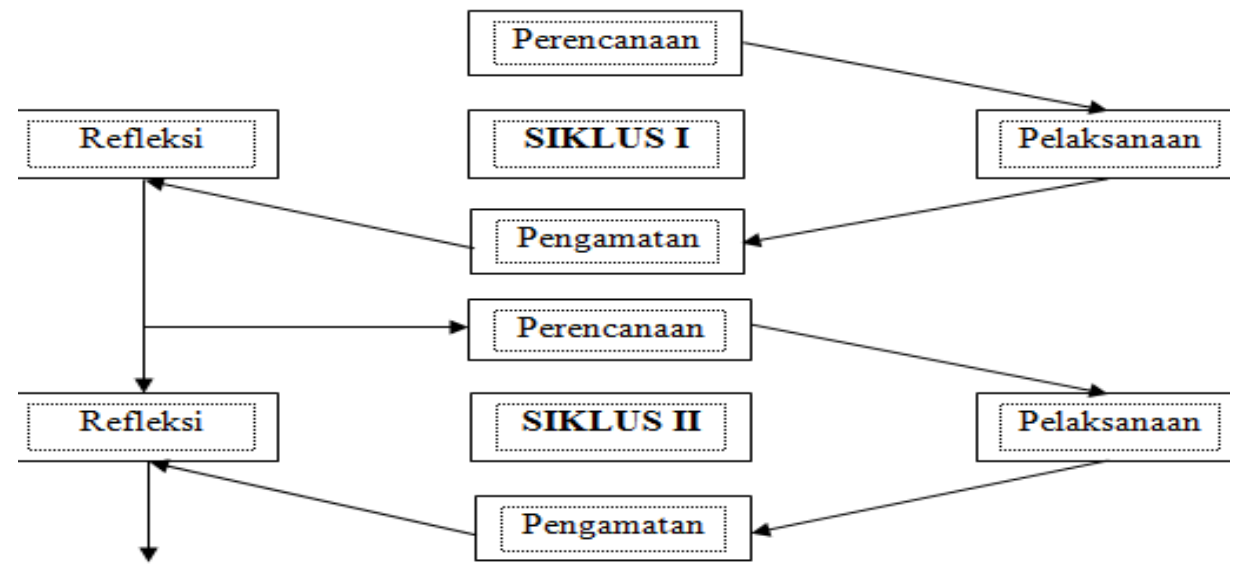

Gambar 1. Rancangan penelitian tindakan kelas

Kegiatan dalam tahap perencanaan ini berupa rancangan kegiatan untuk menentukan langkah-langkah yang akan dilakukan dalam tindakan. Perencanaan tersebut meliputi pengkajian Standar Kompetensi (SK) dan Kompetensi Dasar (KD), penyususnan RPP, dan penetapan target keberhasilan pembelajaran dan memuat instrumen pengamatan untuk merekam fakta yang terjadi selama pembelajaran berlangsung.

Kegiatan yang dilakukan peneliti pada tahap perencanaan siklus 1 pertemuan 1 dengan menyusun RPP dengan materi membandingkan isi resensi dengan menggunakan model Jigsaw, merencanakan media, merancang lembar observasi guru dan siswa, merancang lembar kerja kelompok, dan membuat tes akhir.

Kegiatan yang dilakukan peneliti dalam tahap tindakan yaitu menerapkan rancangan strategi dan rencana pembelajaran. Rancangan tindakan menjelaskan langkah demi langkah kegiatan yang harus dilakukan guru dan siswa untuk meningkatkan hasil siswa tentang teks resensi dengan menggunakan model Jigsaw.

Siklus 1 pertemuan I dilaksanakan satu kali pertemuan dengan alokasi waktu 2 x 45 menit. Kegiatan awal meliputi salam, doa, presensi, apersepsi, penyampaian materi, dan penyampaian tujuan pembelajaran.

Kegiatan inti meliputi tanya jawab antara siswa dengan guru tentang teks resensi. Selanjutnya guru membagi siswa menjadi 7 kelompok asal yang beranggotakan 5 siswa. Kemudian, di dalam kelompok siswa diberi tugas sesuai jumlah materi pelajaran. Kelompok asal berpisah untuk membentuk kelompok ahli untuk mempelajari materi. Siswa kembali ke 
kelompok asal dan menjelaskan materi yang dipelajari di kelompok ahli. Siswa mengerjakan tugas kelompok. Siswa mempresentasikan hasil diskusi. Terakhir siswa mengerjakan tes akhir secara individu.

Kegiatan akhir meliputi penyimpulan materi kegiatan pembelajaran yang telah dilaksanakan. Setelah itu, refleksi pembelajaran, tindak lanjut, doa, dan salam.

Pengamatan dilakukan selama kegitan pembelajaran berlangsung. Pada tahap ini, peneliti dan pengamat (observer) melakukan pengamatan dan mencatat semua hal yang terjadi selama pelaksanaan pembelajaran berlangsung.

Pada waktu kegiatan pembelajaran berlangsung peneliti mencatat apa yang sedang terjadi. Peneliti juga membuat catatan dalam lembar observasi. Objek yang diamati meliputi aktivitas guru dalam melaksanakan pembelajaran dengan menggunakan model Jigsaw, aktivitas siswa selama proses pembelajaran berlangsung dengan menggunakan model Jigsaw, data hasil belajar materi teks resensi melalui model Jigsaw, dan data hasil catatan lapangan.

Tahap refleksi berfungsi untuk mengkaji secara menyeluruh tindakan yang telah dilakukan. Berdasarkan data yang terkumpul dan dilakukan evaluasi yang berguna untuk menentukan target keberhasilan dalam pembelajaran dan menyempurnakan tindakan berikutnya. Demikian seterusnya sampai masalah yang diteliti dapat dipecahkan secara optimal. Tahap-tahap tersebut berlaku untuk siklus berikutnya.

Teknik pengumpulan data melalui teknik tes dan observasi. Tes digunakan untuk mengumpulkan data hasil penelitian dengan menggunakan lembar kerja kelompok dan tes akhir materi teks laporan hasil observasi. Soal tersebut diberikan kepada siswa setelah selesai kegiatan belajar mengajar. Hasil tes ini digunakan untuk mengetahui pemahaman dan keberhasilan siswa dalam menguasai materi yang dipelajari. Alat yang digunakan dalam mengumpulkan data berupa instrumen penilaian pengetahuan, sikap, dan keterampilan.

\section{HASIL DAN PEMBAHASAN \\ Hasil Penelitian \\ Siklus 1 Pertemuan Pertama}

Siklus 1 pertemuan pertama dilaksanakan pada hari Senin, tanggal 12 Maret 2018 dengan alokasi waktu 2 x 45 menit dengan materi tentang struktur Teks Resensi. Dalam pelaksanaan tindakan siklus 1 pertemuan pertama peneliti didampingi oleh seorang pengamat yang melakukan pengamatan selama proses pembelajaran berlangsung. Pada pertemuan ini peneliti (guru) mengajar dengan menggunakan model Jigsaw. Pembelajaran pada pertemuan ini dibagi menjadi 3 tahap, yaitu kegiatan awal (10 menit), kegiatan inti (65 menit), dan kegiatan akhir (15 menit).

Kegiatan awal yang dilakukan oleh guru mengucapkan salam, berdoa bersama siswa, dan melakukan absensi. Kemudian, guru menyampaikan apersepsi melalui tanya jawab dengan siswa tentang struktur Teks Resensi. Kegiatan tersebut berfungsi untuk menggali pengetahuan awal siswa tentang struktur Teks Resensi. Kemudian, guru menginformasikan kepada siswa tentang materi yang akan dipelajari serta tujuan dari mempelajarai materi tersebut. Guru juga menjelaskan model pembelajaran Jigsaw kepada siswa.

Kegiatan inti yang dilakukan oleh guru membentuk kelompok. Siswa dibagi menjadi 7 kelompok yang masing-masing kelompok beranggotakan 5 siswa. Siswa menempati tempat duduk yang telah ditentukan guru sebelumnya. Setiap kelompok menerima nomor anggota dan lembar kerja siswa. Siswa dalam kelompok asli saling berpisah dan bergabung dengan kelompok baru yang beranggotakan siswa yang memiliki kode soal yang sama (kelompok ahli).

Siswa bergabung dengan anggota kelompok ahlinya sesuai dengan arahan guru. Siswa berdiskusi untuk menyelesaikan soal yang telah diterima sesuai dengan petunjuk yang diberikan guru, bersama-sama dengan kelompok ahli. Guru memfasilitasi siswa dalam diskusi untuk soal yang tidak dimengerti. Siswa saling memastikan bahwa setiap anggota mengerti mengenai topik yang dibahas. Guru mengamati aktivitas dan sikap siswa. 
Siswa kembali ke kelompok asli setelah selesai berdiskusi tentang materi dengan kelompok ahli dengan arahan guru. Siswa bergantian menjelaskan mengenai materi yang telah diselesaikan dengan kelompok ahli sebelumnya kepada anggota kelompok asli serta guru mengamati sikap siswa. Kelompok asli mempresentasikan hasil diskusi dengan anggota kelompok di depan kelas. Siswa dan guru bersama-sama membahas soal yang telah diselesaikan dan dipresentasikan.

Pada kegiatan akhir siswa bersama-sama dengan guru menarik kesimpulan tentang pembelajaran yang sudah dilaksanakan. Kemudian guru membagikan lembar tes akhir kepada siswa untuk dikerjakan secara individu. Tes akhir tersebut berfungsi untuk memperkuat pemahaman siswa tentang materi yang baru dipelajari. Setelah kegiatan tersebut, siswa bersama dengan guru merefleksi proses pembelajaran yang telah dilakukan. Guru mengakhiri pembelajaran dengan doa bersama siswa dan salam.

Berdasarkan hasil pengamatan/observasi dan hasil tes selama proses pembelajaran Siklus 1 pertemuan pertama dapat dilihat pada Tabel 1.

Tabel 2. Hasil Tes Siklus I Pertemuan Pertama

\begin{tabular}{|c|l|c|}
\hline No. & \multicolumn{1}{|c|}{ Uraian } & Hasil Siklus 1 Pertemuan Pertama \\
\hline 1. & Skor aktivitas guru & 94 \\
\hline 2. & Skor aktivitas siswa & 60 \\
\hline 3. & Nilai rata-rata tugas kelompok & 70 \\
\hline 4. & Nilai rata-rata tes akhir & 82 \\
\hline 5. & Nilai rata-rata sikap & 83 \\
\hline 6. & Nilai rata-rata keterampilan & 70 \\
\hline & Nilai rata-rata akhir & 76 \\
\hline & Persentase ketuntasan belajar & $64 \%$ \\
\hline
\end{tabular}

\section{Siklus 1 Pertemuan kedua}

Siklus 1 pertemuan kedua dilaksanakan pada hari Senin, tanggal 26 Maret 2018 dengan alokasi waktu 2 x 45 menit dengan materi tentang menyusun resensi dengan memperhatikan hasil perbandingan beberapa teks resensi. Dalam pelaksanaan tindakan siklus 1 pertemuan kedua peneliti didampingi oleh seorang pengamat yang melakukan pengamatan selama proses pembelajaran berlangsung. Pada pertemuan ini peneliti (guru) mengajar dengan menggunakan model Jigsaw. Pembelajaran pada pertemuan ini dibagi menjadi 3 tahap, yaitu kegiatan awal (10 menit), kegiatan inti (65 menit), dan kegiatan akhir (15 menit).

Kegiatan awal yang dilakukan oleh guru mengucapkan salam, berdoa bersama siswa, dan melakukan absensi. Kemudian, guru menyampaikan apersepsi melalui tanya jawab dengan siswa tentang menyusun resensi dengan memperhatikan hasil perbandingan beberapa teks resensi. Kegiatan tersebut berfungsi untuk menggali pengetahuan awal siswa tentang cara menyusun teks resensi. Kemudian, guru menginformasikan kepada siswa tentang materi yang akan dipelajari serta tujuan dari mempelajarai materi tersebut. Guru juga menjelaskan model pembelajaran Jigsaw kepada siswa.

Kegiatan inti yang dilakukan oleh guru membentuk kelompok. Siswa dibagi menjadi 6 kelompok yang masing-masing kelompok beranggotakan 6 siswa. Siswa menempati tempat duduk yang telah ditentukan guru sebelumnya. 
Setiap kelompok menerima nomor anggota dan lembar kerja siswa. Siswa dalam kelompok asli saling berpisah dan bergabung dengan kelompok baru yang beranggotakan siswa yang memiliki kode soal yang sama (kelompok ahli).

Siswa bergabung dengan anggota kelompok ahlinya sesuai dengan arahan guru. Siswa berdiskusi untuk menyelesaikan soal yang telah diterima sesuai dengan petunjuk yang diberikan guru, bersama-sama dengan kelompok ahli. Guru memfasilitasi siswa dalam diskusi untuk soal yang tidak dimengerti. Siswa saling memastikan bahwa setiap anggota mengerti mengenai topik yang dibahas. Guru mengamati aktivitas dan sikap siswa.

Siswa kembali ke kelompok asli setelah selesai berdiskusi tentang materi dengan kelompok ahli dengan arahan guru. Siswa bergantian menjelaskan mengenai materi yang telah diselesaikan dengan kelompok ahli sebelumnya kepada anggota kelompok asli serta guru mengamati sikap siswa. Kelompok asli mempresentasikan hasil diskusi dengan anggota kelompok di depan kelas. Siswa dan guru bersama-sama membahas soal yang telah diselesaikan dan dipresentasikan.

Pada kegiatan akhir siswa bersama-sama dengan guru menarik kesimpulan tentang pembelajaran yang sudah dilaksanakan. Kemudian guru membagikan lembar tes akhir kepada siswa untuk dikerjakan secara individu. Tes akhir tersebut berfungsi untuk memperkuat pemahaman siswa tentang materi yang baru dipelajari. Setelah kegiatan tersebut, siswa bersama dengan guru merefleksi proses pembelajaran yang telah dilakukan. Guru mengakhiri pembelajaran dengan doa bersama siswa dan salam.

Berdasarkan hasil pengamatan/observasi dan hasil tes selama proses pembelajaran

Siklus 1 pertemuan kedua dapat dilihat pada Tabel 2.

Tabel 2. Hasil Tes Siklus I Pertemuan Kedua

\begin{tabular}{|c|l|c|}
\hline No. & \multicolumn{1}{|c|}{ Uraian } & Hasil Siklus 1 Pertemuan kedua \\
\hline 1. & Skor aktivitas guru & 94 \\
\hline 2. & Skor aktivitas siswa & 70 \\
\hline 3. & Nilai rata-rata tugas kelompok & 82 \\
\hline 4. & Nilai rata-rata tes akhir & 71 \\
\hline 5. & Nilai rata-rata sikap & 84 \\
\hline 6. & Nilai rata-rata keterampilan & 71 \\
\hline & Nilai rata-rata akhir & 77 \\
\hline & Persentase ketuntasan belajar & $61 \%$ \\
\hline
\end{tabular}

Adapun penerapan model pembelajaran Jigsaw pada mata pelajaran Bahasa Indonesia pada siklus 1 sudah berjalan dengan lancar. Guru sudah sangat baik dalam pelaksanaan pembelajaran sesuai dengan RPP yang telah dibuat sebelumnya. Namun, masih ada langkah pembelajaran yang belum dilaksanakan. Dari hasil yang telah diperoleh aktivitas guru pada siklus 1 pertemuan pertama memperoleh 15 poin dengan persentase sebesar $94 \%$ dan pada pertemuan 2 memperoleh 15 poin dengan persentase sebesar 94\% sehingga pada siklus 1 ketuntasan aktivitas guru mendapatkan rata-rata persentase sebesar 94\% dengan kualifikasi sangat baik.

Data aktivitas pembelajaran siswa pada siklus 1 pertemuan pertama memperoleh 6 poin dengan persentasi $60 \%$. Sedangkan aktivitas siswa siklus 1 pertemuan kedua memperoleh 7 poin dengan persentase $70 \%$ sehingga pada siklus 1 aktivitas siswa memperoleh presentase rata- rata sebesar $65 \%$. 
Berdasarkan hasil refleksi siklus 1 ada penurunan ketuntasan belajar di siklus 1 pertemuan kedua. Penyebabnya karena turunnya rata-rata nilai tes akhir. Siklus 1 pertemuan pertama rata-rata nilai tes akhir 82 sedangkan di siklus 1 pertemuan kedua rata-rata nilai tes akhir 71. Hal ini dikarenakan materi di siklus 1 pertemuan kedua lebih sulit dibandingkan siklus 1 pertemuan pertama.

\section{Siklus 2 Pertemuan Pertama}

Siklus 2 pertemuan pertama dilaksanakan pada hari Rabu, tanggal 28 Maret 2018 dengan alokasi waktu 2 x 45 menit dengan materi menganalisis kebahasaan resensi dari dua karya yang berbeda. Dalam pelaksanaan tindakan siklus 2 pertemuan pertama peneliti didampingi oleh seorang pengamat yang melakukan pengamatan selama proses pembelajaran berlangsung. Pada pertemuan ini peneliti (guru) mengajar dengan menggunakan model Jigsaw. Pembelajaran pada pertemuan ini dibagi menjadi 3 tahap, yaitu kegiatan awal (10 menit), kegiatan inti (65 menit), dan kegiatan akhir (15 menit).

Kegiatan awal yang dilakukan oleh guru mengucapkan salam, berdoa bersama siswa, dan melakukan absensi. Kemudian, guru menyampaikan apersepsi melalui tanya jawab dengan siswa tentang struktur kebahasaan resensi. Kegiatan tersebut berfungsi untuk menggali pengetahuan awal siswa tentang kebahasaan resensi. Kemudian, guru menginformasikan kepada siswa tentang materi yang akan dipelajari serta tujuan dari mempelajarai materi tersebut. Guru juga menjelaskan model pembelajaran Jigsaw kepada siswa.

Kegiatan inti yang dilakukan oleh guru membentuk kelompok. Siswa dibagi menjadi 9 kelompok yang masing-masing kelompok beranggotakan 4 siswa. Siswa menempati tempat duduk yang telah ditentukan guru sebelumnya.

Setiap kelompok menerima nomor anggota dan lembar kerja siswa. Siswa dalam kelompok asli saling berpisah dan bergabung dengan kelompok baru yang beranggotakan siswa yang memiliki kode soal yang sama (kelompok ahli).

Siswa bergabung dengan anggota kelompok ahlinya sesuai dengan arahan guru. Siswa berdiskusi untuk menyelesaikan soal yang telah diterima sesuai dengan petunjuk yang diberikan guru, bersama-sama dengan kelompok ahli. Guru memfasilitasi siswa dalam diskusi untuk soal yang tidak dimengerti. Siswa saling memastikan bahwa setiap anggota mengerti mengenai topik yang dibahas. Guru mengamati aktivitas dan sikap siswa.

Siswa kembali ke kelompok asli setelah selesai berdiskusi tentang materi dengan kelompok ahli dengan arahan guru. Siswa bergantian menjelaskan mengenai materi yang telah diselesaikan dengan kelompok ahli sebelumnya kepada anggota kelompok asli serta guru mengamati sikap siswa. Kelompok asli mempresentasikan hasil diskusi dengan anggota kelompok di depan kelas. Siswa dan guru bersama-sama membahas soal yang telah diselesaikan dan dipresentasikan.

Pada kegiatan akhir siswa bersama-sama dengan guru menarik kesimpulan tentang pembelajaran yang sudah dilaksanakan. Kemudian guru membagikan lembar tes akhir kepada siswa untuk dikerjakan secara individu. Tes akhir tersebut berfungsi untuk memperkuat pemahaman siswa tentang materi yang baru dipelajari. Setelah kegiatan tersebut, siswa bersama dengan guru merefleksi proses pembelajaran yang telah dilakukan. Guru mengakhiri pembelajaran dengan doa bersama siswa dan salam.

Untuk memudahkan pemahaman dan pembacaan, hasil penelitian dideskripsikan terlebih dahulu, dilanjutkan bagian pembahasan. Subjudul hasil dan subjudul pembahasan disajikan terpisah. Bagian ini harus menjadi bagian yang paling banyak, minimum $60 \%$ dari keseluruhan badan artikel.

Berdasarkan hasil pengamatan/observasi dan hasil tes selama proses pembelajaran Siklus 2 pertemuan pertama dapat dilihat pada Tabel 3. 
Tabel 3. Hasil Tes Siklus II Pertemuan Pertama

\begin{tabular}{|c|l|c|}
\hline No. & \multicolumn{1}{|c|}{ Uraian } & $\begin{array}{c}\text { Hasil Siklus 2 Pertemuan } \\
\text { pertama }\end{array}$ \\
\hline 1. & Skor aktivitas guru & 94 \\
\hline 2. & Skor aktivitas siswa & 80 \\
\hline 3. & Nilai rata-rata tugas kelompok & 77 \\
\hline 4. & Nilai rata-rata tes akhir & 77 \\
\hline 5. & Nilai rata-rata sikap & 85 \\
\hline 6. & Nilai rata-rata keterampilan & 77 \\
\hline & Nilai rata-rata akhir & 79 \\
\hline & Persentase ketuntasan belajar & $64 \%$ \\
\hline
\end{tabular}

\section{Siklus 2 Pertemuan kedua}

Siklus 2 pertemuan kedua dilaksanakan pada hari Senin, tanggal 16 April 2018 dengan alokasi waktu 2 x 45 menit dengan materi tentang mengontruksi resensi novel. Dalam pelaksanaan tindakan siklus 2 pertemuan kedua peneliti didampingi oleh seorang pengamat yang melakukan pengamatan selama proses pembelajaran berlangsung. Pada pertemuan ini peneliti (guru) mengajar dengan menggunakan model Jigsaw. Pembelajaran pada pertemuan ini dibagi menjadi 3 tahap, yaitu kegiatan awal (10 menit), kegiatan inti (65 menit), dan kegiatan akhir (15 menit).

Kegiatan awal yang dilakukan oleh guru mengucapkan salam, berdoa bersama siswa, dan melakukan absensi. Kemudian, guru menyampaikan apersepsi melalui tanya jawab dengan siswa tentang menyusun resensi dengan memperhatikan hasil perbandingan beberapa teks resensi. Kegiatan tersebut berfungsi untuk menggali pengetahuan awal siswa tentang cara menyusun teks resensi. Kemudian, guru menginformasikan kepada siswa tentang materi yang akan dipelajari serta tujuan dari mempelajarai materi tersebut. Guru juga menjelaskan model pembelajaran Jigsaw kepada siswa.

Kegiatan inti yang dilakukan oleh guru membentuk kelompok. Siswa dibagi menjadi 6 kelompok yang masing-masing kelompok beranggotakan 6 siswa. Siswa menempati tempat duduk yang telah ditentukan guru sebelumnya.

Setiap kelompok menerima nomor anggota dan lembar kerja siswa. Siswa dalam kelompok asli saling berpisah dan bergabung dengan kelompok baru yang beranggotakan siswa yang memiliki kode soal yang sama (kelompok ahli).

Siswa bergabung dengan anggota kelompok ahlinya sesuai dengan arahan guru. Siswa berdiskusi untuk menyelesaikan soal yang telah diterima sesuai dengan petunjuk yang diberikan guru, bersama-sama dengan kelompok ahli. Guru memfasilitasi siswa dalam diskusi untuk soal yang tidak dimengerti. Siswa saling memastikan bahwa setiap anggota mengerti mengenai topik yang dibahas. Guru mengamati aktivitas dan sikap siswa.

Siswa kembali ke kelompok asli setelah selesai berdiskusi tentang materi dengan kelompok ahli dengan arahan guru. Siswa bergantian menjelaskan mengenai materi yang telah diselesaikan dengan kelompok ahli sebelumnya kepada anggota kelompok asli serta guru mengamati sikap siswa. Kelompok asli mempresentasikan hasil diskusi dengan anggota kelompok di depan kelas. Siswa dan guru bersama-sama membahas soal yang telah diselesaikan dan dipresentasikan.

Pada kegiatan akhir siswa bersama-sama dengan guru menarik kesimpulan tentang pembelajaran yang sudah dilaksanakan. Kemudian guru membagikan lembar tes akhir kepada 
siswa untuk dikerjakan secara individu. Tes akhir tersebut berfungsi untuk memperkuat pemahaman siswa tentang materi yang baru dipelajari. Setelah kegiatan tersebut, siswa bersama dengan guru merefleksi proses pembelajaran yang telah dilakukan. Guru mengakhiri pembelajaran dengan doa bersama siswa dan salam.

Berdasarkan hasil pengamatan/observasi dan hasil tes selama proses pembelajaran Siklus 2 pertemuan kedua dapat dilihat pada Tabel 4.

Tabel 4. Hasil Tes Siklus II Pertemuan Kedua

\begin{tabular}{|c|l|c|}
\hline No. & \multicolumn{1}{|c|}{ Uraian } & $\begin{array}{c}\text { Hasil Siklus 2 Pertemuan } \\
\text { kedua }\end{array}$ \\
\hline 1. & Skor aktivitas guru & 100 \\
\hline 2. & Skor aktivitas siswa & 100 \\
\hline 3. & Nilai rata-rata tugas kelompok & 84 \\
\hline 4. & Nilai rata-rata tes akhir & 88 \\
\hline 5. & Nilai rata-rata sikap & 85 \\
\hline 6. & Nilai rata-rata keterampilan & 80 \\
\hline & Nilai rata-rata akhir & 84 \\
\hline & Persentase ketuntasan belajar & $97 \%$ \\
\hline
\end{tabular}

Hasil yang telah diperoleh dari aktivitas guru pada siklus 2 menunjukan bahwa guru telah melaksanakan langkah-langkah pembelajaran dengan sangat baik juga. Hal ini ditunjukkan dengan perolehan persentase aktivitas guru pada pertemuan 1 memperoleh poin 15 dengan persentase sebesar $94 \%$ dan pada pertemuan 2 memperoleh poin 16 dengan persentase sebesar $100 \%$ sehingga pada siklus 2 ketuntasan aktivitas guru mendapatkan rata-rata persentase sebesar $97 \%$ dengan kualifikasi sangat baik. Ini menunjukkan bahwa guru sudah melakukan langkah-langkah Jigsaw dengan benar.

Sedangkan dari aktivitas pembelajaran siswa pada siklus 2, keaktifan siswa dalam pembelajaran sudah muncul. Dari data yang diperoleh menunjukkan persentase aktivitas siswa pada siklus 2 pertemuan pertama memperoleh 8 poin dengan persentase sebesar $80 \%$ dan pada pertemuan 2 memperoleh poin sebesar 10 dengan persentase sebesar $100 \%$ sehingga pada siklus 2 aktivitas siswa memperoleh presentase rata-rata sebesar 90\%. Hal ini menunjukkan bahwa siswa telah menunjukkan aktivitas yang positif pada siklus 2 ketika diterapkan model pembelajaran Jigsaw.

Berdasarkan hasil refleksi siklus 2 ada peningkatan ketuntasan belajar di siklus 2 pertemuan kedua yang sangat bagus. Penyebabnya karena rata-rata nilai tes akhir meningkat. Siklus 2 pertemuan pertama rata-rata nilai tes akhir 77 sedangkan di siklus 2 pertemuan kedua rata-rata nilai tes akhir 88. Sedangkan persentase ketuntasan Siklus 2 pertemuan pertama $64 \%$ dan Siklus 2 pertemuan kedua 97\%.

Tabel. 5 Perbandingan hasil belajar peserta didik pada siklus 1 dan siklus 2

\begin{tabular}{|c|l|c|c|}
\hline No. & \multicolumn{1}{|c|}{ Uraian } & Hasil Siklus 1 & Hasil Siklus 2 \\
\hline 1. & Rata-rata skor aktivitas guru & 94 & 97 \\
\hline 2. & Rata-rata skor aktivitas siswa & 65 & 90 \\
\hline
\end{tabular}




\begin{tabular}{|c|l|c|c|}
\hline 3. & Rata-rata nilai tugas kelompok & 76 & 80,5 \\
\hline 4. & Rata-rata nilai tes akhir & 76,5 & 82,5 \\
\hline 5. & Rata-rata nilai sikap & 83,5 & 85 \\
\hline 6. & Rata-rata nilai keterampilan & 70,5 & 78,5 \\
\hline & Rata-rata nilai akhir & 76,5 & 81,5 \\
\hline & Persentase ketuntasan belajar & $62,5 \%$ & $80,5 \%$ \\
\hline
\end{tabular}

Berdasarkan pada tabel 5 di atas, dapat diketahui bahwa hasil belajar peserta didik kelas XI MIA 2 MAN 3 Blitar yang mengikuti pembelajaran dengan penerapan model Jigsaw mengalami peningkatan dari siklus I ke Siklus 2 dari rata-rata nilai akhir 76,5 di siklus 1 menjadi 81,5 di siklus 2. Sedangkan ketuntasan klasikal mengalami peningkatan dari $62,5 \%$ di siklus 1 menjadi 80,5\% di siklus 2 .

\section{Pembahasan}

Berdasarkan data yang diperoleh dari aktivitas guru dan siswa pada pelajaran Bahasa Indonesia materi teks resensi pada siswa kelas XI MIA 2 MAN 3 Blitar dapat disimpulkan bahwa guru sudah menerapkan pembelajaran model Jigsaw. Selain itu, aktivitas belajar siswa juga mengalami peningkatkan.

Hal ini sejalan dengan pendapatnya (Soekamto dkk. dalam Kuntjojo dkk., 2011) yang menyatakan bahwa model pembelajaran merupakan salah satu aspek penting bagi seorang guru dalam proses pembelajaran. Model pembelajaran adalah kerangka konseptual yang melukiskan prosedur yang sistematis dalam mengorganisasikan pengalaman belajar untuk mencapai tujuan belajar tertentu, dan berfungsi sebagai pedoman bagi para perancang pembelajaran dan para pengajar dalam merencanakan aktivitas belajar mengajar. Dengan pemilihan model belajar yang tepat akan ada peningkatan hasil belajar.

Hasil belajar materi teks resensi melalui model Jigsaw pada siswa kelas XI MIA 2 MAN 3 Blitar diperoleh dari hasil penelitian melalui rata-rata nilai akhir pada siklus 1 pertemuan 1 dengan persentase $76 \%$. Pada siklus 1 pertemuan kedua dengan persentase $77 \%$ dengan ratarata persentase $76,5 \%$. Sedangkan pada siklus 2 pertemuan 1 dengan persentase $79 \%$ dan untuk siklus 2 pertemuan kedua dengan persentase $84 \%$ dengan rata-rata persentase $81,5 \%$. Jadi, ada peningkatan dari siklus 1 sebesar 76,5\% ke siklus 2 sebesar $81,5 \%$. Rata-rata persentase siklus 1 dan siklus 2 sebesar $79 \%$ dengan kualifikasi baik.

Peningkatan hasil belajar ini dikarenakan pemilihan model Jigsaw dapat menciptakan situasi keberhasilan individu yang ditentukan oleh keberhasilan kelompoknya. Sistem ini berbeda dengan kelompok konvensional yang menerapkan sistem kompetisi dan keberhasilan individu diorientasikan pada kegagalan orang lain. Untuk itu, kekompakan dan dan kerja sama yang solid antarkelompok menentukan berhasil dan tidaknya pembelajaran tersebut karena satu sama lain akan memberikan informasi yang telah didapat dari kelompok lain (Slavin (2005).

Hasil belajar siswa pada siklus 1 rata-rata persentase ketuntasan siswa mencapai 76,5\% dan siklus 2 rata-rata persentase 81,5\%. Hasil ini menunjukkan bahwa model Jigsaw dapat digunakan untuk meningkatkan hasil belajar bahasa Indonesia materi teks resensi di kelas XI MIA 2 MAN 3 Blitar.

Peningkatan hasil belajar siswa memberikan gambaran adanya perhatian dan pemahaman siswa terhadap pembelajaran. Dampak dari adanya perhatian dan pemahaman siswa terhadap pembelajaran juga ditunjukkan dengan peningkatan ketuntasan belajar secara umum. Peningkatan tersebut menunjukkan perbandingan rata-rata penilaian hasil pada siklus pertama dan siklus kedua. 
Setelah dilakukan penelitian menggunakan model Jigsaw dengan materi teks resensi dengan jumlah siswa 36 pada siklus 1 pertemuan pertama terdapat 13 siswa (36\%) yang belum tuntas dan yang tuntas 23 siswa (64\%). Sedangkan pada siklus 1 pertemuan kedua terdapat 14 siswa (39\%) dan yang tuntas sebanyak 22 siswa (61\%). Ini menunjukan terdapat penurunan jumlah ketuntasan siswa pada siklus 1 . Sedangkan pada siklus 2 pertemuan pertama terdapat 13 siswa (36\%) yang belum tuntas dan yang tuntas 23 siswa (64\%). Sedangkan pada siklus 2 pertemuan 2 terdapat 1 siswa (3\%) dan yang tuntas sebanyak 35 siswa (97\%). Ini menunjukan terdapat kenaikan jumlah ketuntasan siswa pada siklus 2 .

Adanya siswa yang belum tuntas dikarenakan siswa kurang teliti dalam menjawab soal, selain itu juga dipengaruhi oleh tingkat mudah atau sulitnya materi. Peningkatan hasil belajar siswa setelah menggunakan model Jigsaw dipengaruhi oleh keaktifan dan kerjasama siswa yang baik selama pembelajaran serta kemampuan siswa dalam memahami materi teks resensi.

Berdasarkan hasil temuan pada siklus 1 dan siklus 2 dapat dijabarkan temuan lengkap selama pembelajaran sebagai berikut. Proses kegiatan belajar siswa mengalami peningkatan. Hasil belajar siswa baik aspek pengetahuan, sikap, dan keterampilan mengalami peningkatan. Peningkatan pengetahuan siswa dapat dilihat dari hasil belajar siswa yang diperoleh. Peningkatan sikap siswa dapat dilihat dari sikap yang ditampilkan siswa selama pembelajaran berupa keaktifan, kerjasama, dan partisipasi siswa. Peningkatan aspek keterampilan siswa dapat dilihat pada saat siswa menyampaikan hasil diskusinya. Jadi, penggunaan model Jigsaw dapat meningkatkan hasil belajar siswa.

\section{KESIMPULAN}

Sesuai hasil penelitian dan pembahasan, maka dapat dikemukakan bahwa setelah dilakukan tindakan dengan menggunakan penerapan model Jigsaw pada peserta didik kelas XI MIA 2 MAN 3 Blitar terjadi peningkatan hasil belajar dan ketuntasan belajarnya. Perubahan ini nampak pada hasil observasi maupun tes akhir pada siklus 1, dan tindakan dari siklus 2 . Data perkembangan hasil peningkatan hasil belajar peserta didik dapat dilihat dari rata-rata perolehan nilai peserta didik pada masing-masing siklus mengalami peningkatan yakni pada siklus 1 rata-rata hasil belajar 76,5 pada siklus 1 menjadi 81,5 pada siklus 2 . Persentase ketuntasan belajar juga mengalami peningkatan dari 76,5 pada siklus 1 menjadi 81,5 pada siklus 2. Dengan hasil penelitian ini, penulis menyarankan kiranya rekan-rekan guru yang lain dapat mencoba menerapkan model Jigsaw pada materi lain yang lebih kompleks.

\section{DAFTAR PUSTAKA}

Astuti, Dhian Dwi. 2015. Peningkatan Hasil Belajar Matematika pada Bilangan Pecahan melalui Model Numbered Heads Together Di Kelas IV SDN Ampelgading 02 Kabupaten Blitar. Skripsi. Malang: Universitas Negeri Malang.

Budiyanto. 2004. Pengertian Model Pembelajaran. (Online), (http://belajarpsikologi.com/pengertian-model-pembelajaran/, diakses 10 Februari 2018).

Kuntjojo dkk., 2011. Modul Model-model Pembelajaran. Modul disajikan dalam Pendidikan dan Latihan Guru Profesional PSG Rayon Universitas Nusantara PGRI Kediri.

Roestiyah. 1998. Strategi Belajar Mengajar. Jakarta: Rineka Cipta.

Slavin, E Robert. 2005. Cooperative Learning. Bandung : Penerbit Nusa Media.

Zamzani, Eki Tirtana. 2015. Penerapan Metode Jigsaw dalam Pembelajaran, (online) (https://www.kompasiana.com/www.etzcoy.blogspot.com/penerapan-metode-jigsawdalam-pembelajaran_5605f7b57fafbde10e17baec, diakses 20 Januari 2018). 